\title{
Human Capital in Agriculture Sector in Indonesia
}

\author{
Eny Lestari Widarni \\ (STIE Jaya Negara Tamansiswa Malang) \\ Benjamin Drean \\ (Lycée George Sand, EPL du Velay)
}

\begin{abstract}
This study aims to examine the role of education and health in increasing work participation and income of the people in Indonesia. To achieve this goal, data on GDP per capita, Employment in Agriculture, Health, and education are observed. This study uses the Quantitative Threshold Autoregressive method which is used to predict the behavior of the data so that the relationship behavior between the data can be seen. In analyzing the threshold variable, the GDP per capita variant is used as an indicator of people's income growth, Employment in agriculture as work participation in the agricultural sector, health as an indicator of health investment, and education as an indicator of educational investment. GDP per capita, Employment in agriculture, and health as the threshold variable. Meanwhile, the non-threshold variable is education. All data are secondary data from world banks with an annual period of $2000-2019$. We found that education and health are two things that form the basis of human capital. The role of education and health in Indonesia in developing agriculture and improving the welfare of the people in Indonesia plays an important role and is able to make a significant contribution to the development of the agricultural sector and the welfare of the people in Indonesia.
\end{abstract}

Keywords: Human Capital, Agriculture, Gross Domestic Product Per Capita

\section{Introduction}

The industrial revolution 4.0 has had a positive impact on various sectors including the agricultural sector (Kumar et al,2021). However, the contribution of innovation in the development of the Indonesian agricultural sector is still very small. Agricultural development in Indonesia still relies on human resources so that human capital is very important in the development of the agricultural sector in Indonesia (Santika et al,2019).

The key to the success of accelerating the transformation of modern agricultural development in Indonesia lies in the quality of agricultural human resources (human capital) which will leverage comparative advantages to become competitive. There needs to be a breakthrough in the development of smart agricultural technology that can be implemented with the right input, the right amount, the right time, and the right place. However, with the current level of technological readiness, efforts to accelerate the process of agricultural development based on technological innovation are considered quite heavy. Agricultural technology functions to optimize cultivation systems, control pests and diseases, optimize 
the use of agricultural resources to increase productivity and quality of agricultural products through proper post-harvest handling (Moeis et al,2020).

The element of human capital or human capital in the modern agricultural system has a significant role in the process of developing intelligent agricultural technology. Indicators of the implementation of human capital in this technological innovation can be measured from the level of productivity achieved and the financial aspects of the agricultural system implementation. In addition, it also increases the ability to innovate and the entrepreneurial spirit of agricultural human resources (Gras \& Cáceres,2020).

The development of smart agricultural technology based on human capital will provide benefits to each individual and also the human resource community of agricultural system actors if the development model uses a participatory approach. Technology develops in line with education. Where education plays an important role in technology development including agricultural technology (Ahmed et al,2021).

Indonesian human resources to be able to work optimally also need to be maintained and strived to stay healthy so that it can be said that health and education are important pillars in developing human capital, especially in the agricultural sector in Indonesia (Radjab et al,2020). This study examines the development of human capital represented by investment in education and health towards work participation in the agricultural sector and the per capita income of the Indonesian people.

\section{Literature Review}

The progress of a country is determined by three main components that play a role, namely natural resources, human resources, and technology. In its development, the components that dominate are human resources and the use of technology. Developed and developing countries can be seen from the human resources they have and how much use of appropriate technology is (Rahim et al,2021).

In the agricultural sector in Indonesia, the large number of employment opportunities is influenced by the area of agricultural land, land productivity, cropping intensity and pattern, and the technology applied. In the non-agricultural sector, employment opportunities are determined, among other things, by the volume of production, technology, and the level of commodity prices. Provision of labor is influenced, among others, by the level of wages, work comfort, labor mobility, and the rate of increase in the rural labor force (Kirono et al,2016).

Farmers are the main implementers of agricultural development, thus the success of agricultural development is largely determined by the quality of the human resources of the farmers. In the framework of national economic development, the agricultural sector also plays a role in providing labor for other economic sectors, also as a provider of capital, raw materials, and a market for products outside the agricultural sector. Nationally, there has been an increase in the quality of Indonesian workers where the role of workers without formal education has decreased drastically (Berg et al,2020).Education in agriculture is something that needs to be improved in developing human resources in the Indonesian agricultural sector. The superiority of a nation no longer rests solely on natural wealth, but on the superiority of human resources, namely educated personnel who are able to answer very fast challenges.

Education plays a very important role in the development and mastery of technology and in increasing human productivity (Ghosh \& Parab,2021). The birth of the Industrial Revolution 4.0 era made various 
aspects of life inseparable from the role of technology, including in the world of education. Technology is believed to be able to strengthen the world of education, just as technology can strengthen the financial industry, transportation, and all aspects of it. Mastery of technology in the era of the 4th industrial revolution requires education as an effort to increase knowledge, intelligence, and mastery of technology .

Education is very influential in development, be it in the development of human, economic, social resources, and even more so, the role of education in the development of society, the nation, and the State. In this case, education occupies a central position in development because the goal is to improve the quality of human resources. That education can have a large effect on reducing income inequality. So it can be said that education plays a role in increasing income (Suratno et al,2021).

Indonesia is one of the developing countries in the Asian region, with its various natural potentials. This natural potential can be used in mining, forest, plantation, and agriculture. The abundant potential has not been fully utilized, especially in the agricultural sector. Agriculture, which is a potential sector to be developed, has not been supported by adequate human resources. In fact, the human resources in this field tend to experience a decline in interest because the income in this sector is less promising and in terms of social status is still considered low. It is evident that the former agricultural vocational school was abolished because of the reduced interest. To produce quality human resources, it is necessary to develop education that leads to regional development, so that education is not a futile endeavor (Saptutyningsih et al,2020).

Agricultural development will run well if it is supported by quality human resources which are the output of education development so that educational policies that lead to agricultural development play an important role in this regard. One measure of human quality is the high level of education. Apart from personality, the environment (education) affects a person's behavior. In other words, the behavior of farmers with high levels of education is expected to be better than farmers with low levels of education. Agricultural development can be defined as a process of social change. Its implementation is not only aimed at increasing the status and welfare of farmers but at the same time it is also intended to develop the potential of human resources both economically, socially, politically, culturally, environmentally, as well as through improvement, growth, and change (Inwood,2017).

\section{Research Methods and Materials}

This study aims to examine the role of education and health in increasing work participation and income of the people in Indonesia. To achieve this goal, data on GDP per capita, Employment in Agriculture, Health, and education are observed. This study uses the Quantitative Threshold Autoregressive method which is used to predict the behavior of the data so that the relationship behavior between the data can be seen. In analyzing the threshold variable, the GDP per capita variant is used as an indicator of people's income growth, Employment in agriculture as work participation in the agricultural sector, health as an indicator of health investment, and education as an indicator of educational investment. GDP per capita, employment in agriculture, and health as the threshold variable.Meanwhile, the non-threshold variable is education. The hope is that knowing past behavior data can be an indicator of decision-making that can be taken in the future. In this study we used the autoregressive equation as follows:

$\mathrm{AR}_{(\mathrm{p})}=\mathrm{Y}_{\mathrm{t}}=\mathrm{c}+\Phi_{1} \mathrm{Y}_{\mathrm{t}-1}+\Phi_{2} \mathrm{Y}_{\mathrm{t}-2}+\ldots . .+\Phi_{\mathrm{p}} \mathrm{Y}_{\mathrm{t}-\mathrm{p}}+\mathrm{e}_{\mathrm{t}}$ 
Where AR is $\mathrm{Y}$ and $\mathrm{Yt}$ is $\mathrm{Y}$ from time to time in a time series which is influenced by $\mathrm{Yt}-1$ or $\mathrm{Y}$ from time to time in the past in period 1 and Yt-1 itself is also influenced by Yt-2 which is $\mathrm{Y}$ in the past in period 2 onwards which is influenced by et which is the error term for the time in the study period. This study focuses on secondary data sourced from world banks, including data on internet users, consumption and GDP per capita in Indonesia. With the econometric equation as follows:

$Y_{t}=\beta_{0}+\beta_{1} E_{t 1}+\beta_{2} H_{t 2}+\beta_{3} E_{t}+e_{t}$

Where $\mathrm{Y}$ is gross domestic product per capita, $\mathrm{t}$ is a period of time, $\beta$ is constant, Ed is Education, $\mathrm{H}$ is health, EA is Employment in agriculture and e is an error term. All data are secondary data from world banks with an annual period of 2000 - 2019.

\section{Results and Discussion}

In analyzing the threshold variable, the GDP per capita variant is used as an indicator of people's income growth, Employment in agriculture as work participation in the agricultural sector, health as an indicator of health investment, and education as an indicator of educational investment. GDP per capita, employment in agriculture, and health as the threshold variable. Meanwhile, the non-threshold variable is education. The following are the estimation results that we have done:

GDP_PER_CAPITA $=\left(-1863.04271735+4777.92758935^{*}\right.$ EMPLOYMENT_IN_AGRICULTURE + 6.25185614123e-08*HEALTH)

$+$

5154.41079721*EMPLOYMENT_IN_AGRICULTURE

$1.71263639538 \mathrm{e}-08 *$ HEALTH)*@LOGIT(0.0816251085215*(GDP_PER_CAPITA(-3)-3129.956369 $88))+3.86310197985 \mathrm{e}-08 *$ EDUCATION

The estimation results from the first estimate can be seen in table 1 below:

Table 1. Estimation Result

\begin{tabular}{|l|r|r|r|r|}
\hline Variable & \multicolumn{1}{l|}{ Coefficient } & \multicolumn{1}{l|}{ Std. Error } & \multicolumn{1}{l|}{ t-Statistic } & \multicolumn{1}{l|}{ Prob. } \\
\hline & & & & \\
\hline & & & & \\
\hline & & & & \\
\hline Chreshold Variables (linear part) & -1863.043 & 920.2186 & -2.024565 & 0.0775 \\
\hline EMPLOYMENT_IN_AGRICULTURE & 4777.928 & 1941.892 & 2.460449 & 0.0393 \\
\hline HEALTH & $6.25 \mathrm{E}-08$ & $1.46 \mathrm{E}-08$ & 4.278731 & 0.0027 \\
\hline & & & & \\
\hline Threshold Variables (nonlinear part) & & & & \\
\hline & & & & \\
\hline C & 3066.735 & 1771.293 & 1.731354 & 0.1216 \\
\hline EMPLOYMENT_IN_AGRICULTURE & -5154.411 & 3677.896 & -1.401457 & 0.1987 \\
\hline HEALTH & $-1.71 \mathrm{E}-08$ & $2.05 \mathrm{E}-08$ & -0.835922 & 0.4275 \\
\hline & & & & \\
\hline Non-Threshold Variables & & & & \\
\hline & & & & \\
\hline EDUCATION & $3.86 \mathrm{E}-08$ & $1.05 \mathrm{E}-08$ & 3.672539 & 0.0063 \\
\hline & & & & \\
\hline Slopes & & & & \\
\hline & & & & \\
\hline SLOPE & 0.081625 & 5630.924 & $1.45 \mathrm{E}-05$ & \\
\hline
\end{tabular}




\begin{tabular}{|l|r|r|r|}
\hline & & & \\
\hline THRESHOLD & 3129.956 & 548870.9 & 0.005703 \\
\hline & & & \\
\hline R-squared & 0.999137 & Mean dependent var & 2805.471 \\
\hline Adjusted R-squared & 0.998274 & S.D. dependent var & 1084.888 \\
\hline S.E. of regression & 45.07488 & Akaike info criterion & 10.75958 \\
\hline Sum squared resid & 16253.96 & Schwarz criterion & 11.20069 \\
\hline Log likelihood & -82.45642 & Hannan-Quinn criter. & 10.80343 \\
\hline F-statistic & 1157.591 & Durbin-Watson stat & 2.242217 \\
\hline Prob(F-statistic) & 0 & &
\end{tabular}

Source : Data world Bank Compiled

It can be seen that the per capita GDP relationship with all variables is positive. Where the employment in agriculture variable is 4777,928, Health 6.25E-08 and Education 3.86E-08 This means that an increase in work participation is 4778 people, an increase in investment of $6 \%$ and $4 \%$ education can encourage an increase in GDP per capita by $1 \%$. This is certainly a very strong driver for economic growth and the income of the people in Indonesia. To find out the data behavior of all variables that are the object of research in driving per capita income, forecasting results are presented in the following graph:

Figure 1. The results of forecasting GDP percapita

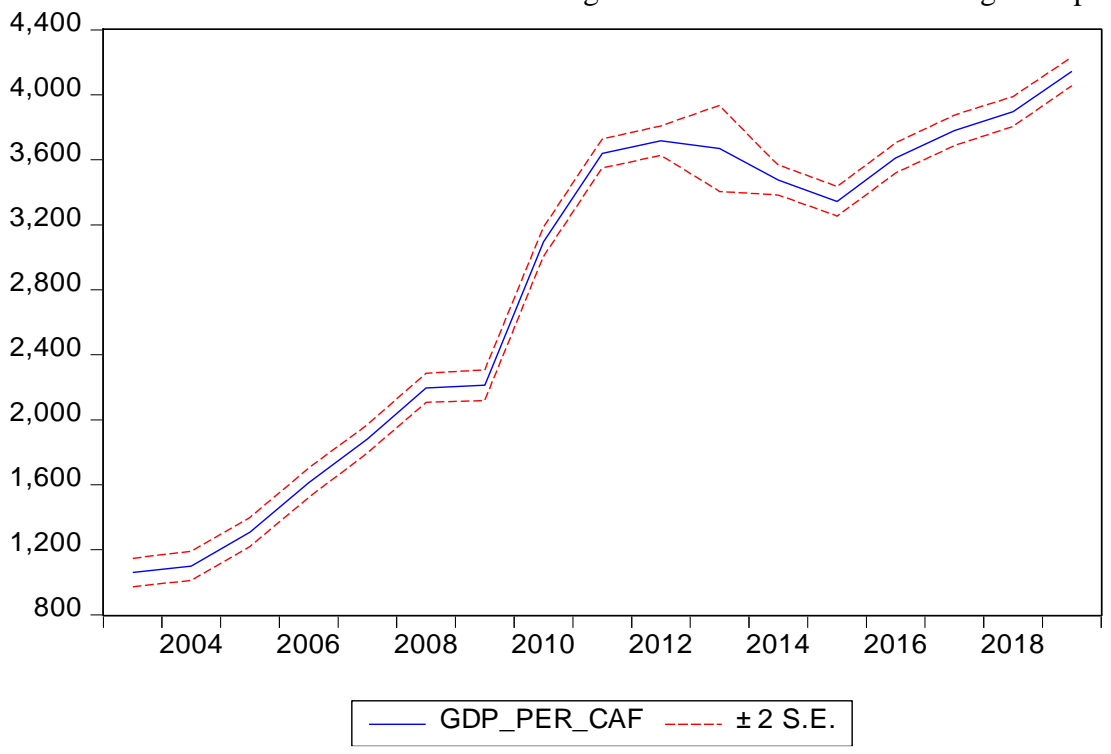

\begin{tabular}{|c|c|}
\hline \multicolumn{2}{|l|}{ Forecast: GDP_PER_CAF } \\
\hline \multicolumn{2}{|l|}{ Actual: GDP_PER_CAPITA } \\
\hline \multicolumn{2}{|l|}{ Forecast sample: 20002019} \\
\hline \multicolumn{2}{|l|}{ Adjusted sample: 20032019} \\
\hline \multicolumn{2}{|l|}{ Included observations: 17} \\
\hline Root Mean Squared Error & 32.98034 \\
\hline Mean Absolute Error & 27.80202 \\
\hline Mean Abs. Percent Error & 1.271028 \\
\hline Theil Inequality Coefficient & 0.005500 \\
\hline Bias Proportion & 0.007842 \\
\hline Variance Proportion & 0.001263 \\
\hline Covariance Proportion & 0.990895 \\
\hline Theil U2 Coefficient & 0.134198 \\
\hline Symmetric MAPE & 1.272623 \\
\hline
\end{tabular}

Source : Data world Bank Compiled

From the forecast results shown in Figure 1, it can be seen that the graph of GDP per capita can be pushed very quickly. This shows that human capital in Indonesia contributes greatly to the income of the people, especially those who work in the agricultural sector.

\section{Conclusions}

Education and health are two things that form the basis of human capital. The role of education and health in Indonesia in developing agriculture and improving the welfare of the people in Indonesia plays an important role and is able to make a significant contribution to the development of the agricultural sector and the welfare of the people in Indonesia. 


\section{References}

Ahmed,Z., Nathaniel,S.P., Shahbaz,M.(2021).The criticality of information and communication technology and human capital in environmental sustainability: Evidence from Latin American and Caribbean countries. Journal of Cleaner Production, Volume 286, 1 March 2021, 125529.https://doi.org/10.1016/j.jclepro.2020.125529

Berg,H.v.d., Ketelaar,J.W., Dicke,M., Fredrix,M.(2020). Is the farmer field school still relevant? Case studies from Malawi and Indonesia. NJAS - Wageningen Journal of Life Sciences, Volume 92, December 2020, 100329. https://doi.org/10.1016/j.njas.2020.100329

Ghosh,T., Parab,P.M. (2021).Assessing India's productivity trends and endogenous growth: New evidence from technology, human capital and foreign direct investment. Economic Modelling, Volume 97, April 2021, Pages 182-195.https://doi.org/10.1016/j.econmod.2021.02.003

Gras,C., Cáceres,D.M.(2020).Technology, nature's appropriation and capital accumulation in modern agriculture.Current Opinion in Environmental Sustainability,Volume 45, August 2020, Pages 1-9.https://doi.org/10.1016/j.cosust.2020.04.001

Inwood,S.(2017).Agriculture, health insurance, human capital and economic development at the rural-urban-interface.Journal of Rural Studies,Volume 54, August 2017, Pages 1-14.https://doi.org/10.1016/j.jrurstud.2017.05.009

Kirono,D.G.C.., Butler,J.R.A., McGregor,J.L., Ripaldi,A., Katzfey,J., Nguyen,K.(2016). Historical and future seasonal rainfall variability in Nusa Tenggara Barat Province, Indonesia: Implications for the agriculture and water sectors. Climate Risk Management,Volume 12, 2016, Pages 45-58.https://doi.org/10.1016/j.crm.2015.12.002

Kumar,S., Raut,R.D., Nayal,K., Kraus,S., Yadav,V.S., Narkhede,B.E. (2021). To identify industry 4.0 and circular economy adoption barriers in the agriculture supply chain by using ISM-ANP. Journal of Cleaner Production,Volume 293, 15 April 2021, 126023. https://doi.org/10.1016/j.jclepro.2021.126023

Moeis,F.R., Dartanto,T., Moeis,J.P., Ikhsan,M.(2020).A longitudinal study of agriculture households in Indonesia: The effect of land and labor mobility on welfare and poverty dynamics. World Development Perspectives, Volume 20, December 2020, 100261.https://doi.org/10.1016/j.wdp.2020.100261

Radjab,M., Unde,A., Lampe,M., Nurlela,A.(2020).The health development inequality of remote village: The study case of Bakaru Village, Indonesia.Enfermería Clínica, Volume 30, Supplement 2, March 2020, Pages 263-266.https://doi.org/10.1016/j.enfcli.2019.07.100

Rahim,S.,Murshed,M., Umarbeyli,S., Kirikkaleli,D., Ahmad,M., Tufail,M., Wahab,S.(2021).Do natural resources abundance and human capital development promote economic growth? A study on the resource curse hypothesis in Next Eleven countries. Resources, Environment and Sustainability, Volume 4, June 2021, 100018.https://doi.org/10.1016/j.resenv.2021.100018

Santika,T., Wilson,K.A., Budiharta,S., Law,E.A., Poh,T.M., Ancrenaz,M., Struebig,M.J., Meijaard,E. (2019). Does oil palm agriculture help alleviate poverty? A multidimensional counterfactual assessment 
of oil palm development in Indonesia. World Development, Volume 120, August 2019, Pages 105-117. https://doi.org/10.1016/j.worlddev.2019.04.012

Saptutyningsih,E., Diswandi,D., Jaung,W.(2020).Does social capital matter in climate change adaptation? A lesson from agricultural sector in Yogyakarta, Indonesia. Land Use Policy, Volume 95, June 2020, 104189.https://doi.org/10.1016/j.landusepol.2019.104189

Suratno., Narmaditya, B.S., Wibowo,A. (2021). Family economic education, peer groups and students' entrepreneurial intention: the mediating role of economic literacy. Heliyon, Volume 7, Issue 4, April 2021, e06692.https://doi.org/10.1016/j.heliyon.2021.e06692 